\title{
Peningkatan Gizi Seimbang dan Deteksi Tumbuh Kembang pada Anak di Masa Pandemi Covid 19
}

\author{
Liza Wati ${ }^{1}$, Wasis Pujiati ${ }^{2}$, Meily Nirnasari ${ }^{3}$ \\ STIKES Hang Tuah Tanjungpinang \\ Email: liza_chintin@yahoo.com
}

Submitted : 28/09/2021

Accepted: 16/10/2021

Published: 19/11/2021

\begin{abstract}
Covid-19 is still not over, this triggers parental concern about the threat of covid-19 to children. For this reason, maintaining immunity is the main concern of parents at this time, one of which is through adequate nutritional intake for children and the importance of early detection of development and growth. growth in toddlers. The purpose of this community service is to increase knowledge related to balanced nutrition in infancy, measurement of weight and height and detection of growth and development using a developmental questionnaire. The method used in the form of counseling, weighing and detecting growth and development with a pre-screening development questionnaire. The result of this activity is increased knowledge related to balanced nutrition, and based on height/age measurements, 1 child is very short and 3 children are short. The next hope is for mothers of toddlers to provide balanced nutrition for the growth and development of their toddlers.
\end{abstract}

Keywords: covid-19, toddler

Abstrak
Covid-19 masih belum berakhir hal ini memicu kekawatiran orangtua terhadap ancaman covid-19 pada anak-anak Untuk itu, menjaga kekebalan tubuh menjadi perhatian utama orang tua saat ini, salah satunya melalui asupan gizi yang cukup bagi anak dan pentingnya deteksi dini terhadap perkembangan dan pertumbuhan pada balita. Tujuan pengabdian masyarakat ini adalah untuk meningkatkan pengetahuan terkait dengan gizi seimbang pada masa balita, pengukuran BB dan TB serta deteksi tumbuh kembang menggunakan kuesioner perkembangan. Metode yang digunakan berupa penyuluhan, penimbangan dan pendeteksian tumbuh kembang dengan kuesioner pra skrining perkembangan. Hasil kegiatan ini adalah bertambahnya pengetahuan terkait dengan gizi seimbang, dan berdasarkan pengukuran TB/U didapatkan 1 anak sangat pendek dan 3 anak pendek. Harapan selanjutnya adalah pada ibu balita untuk memberikan gizi seimbang untuk pertumbuhan dan perkembangan balitanya.

Kata kunci: Covid-19, gizi, balita

\section{PENDAHULUAN}

UNICEF memprediksi pandemi COVID-19 berpotensi memperburuk beban malnutrisi pada anak-anak Indonesia akibat pola makan yang tidak seimbang. Fakta ini kembali memicu kekhawatiran orang tua terhadap ancaman Covid-19 pada anak-anak. Untuk itu, menjaga kekebalan tubuh anak wajib menjadi perhatian utama orang tua saat ini, salah satunya melalui asupan gizi yang cukup bagi anak. Pemilihan makanan untuk anak menjadi penting diperhatikan mengingat zat-zat makanan yang masuk ke tubuh anak yang akan menentukan kekebalan anak terhadap virus dan patogen dari luar. Kesalahan asupan makanan dan minuman untuk anak berisiko anak mudah terserang penyakit karena menurunnya kekebalan dan untuk jangka panjang menyebabkan masalah gizi, yang berakibat mudahnya timbul penyakit tidak menular seperti diabetes dan obesitas hingga menurunkan kualitas anak di masa mendatang ( Handayani,2020)

Anak-anak usia bawah lima tahun (balita) sangat rentan sekali berbagai penyakit sehingga akan berdampak tumbuh kembang terhadap anak tersebut. Hal ini, orang tua wajib manjaga kesehatan anaknya dengan pola makan dan memberi asupan gizi yang baik. Saat pandemi Covid-19 melanda keluarga lebih fokus mencari kebutuhan sehari-hari. Akan tetapi, dengan kesibukan itu orang tua 
masih kurang memperhatikan pola makan balita dan membentuk pola makan yang tidak sehat bagi anak-anak di masa mendatang. Pilihan orang tua itu berkorelasi pada kemampuan daya beli. Karena tidak punya cukup uang, maka kemampuan daya beli berkurang saat pandemi ini, sehingga kemungkinan akan semakin besar pula prosentase berkurangnya keberagaman asupan makan anak-anak balita ini ( Dimas Rahadian, $2020)$

Stimulasi adalah kegiatan merangsang kemampuan dasar anak umur 0-6 tahun agar anak tumbuh dan berkembang secara optimal. Setiap anak perlu mendapat stimulasi rutin sedini mungkin dan terus menerus pada setiap kesempatan. Stimulasi tumbuh kembang anak dilakukan oleh ibu dan ayah yang merupakan orang terdekat dengan anak, pengganti ibu/pengasuh anak, anggota keluarga lain dan kelompok masyarakat di lingkungan rumah tangga masing-masing dan dalam kehidupan sehari-hari. Kurangnya stimulasi dapat menyebabkan penyimpangan tumbuh kembang anak bahkan gangguan yang menetap (Kemenkes RI, 2016). Instrumen yang digunakan untuk mengetahui perkembangan anak normal atau ada penyimpangan adalah Kuesioner Pra Skrining Perkembangan (KPSP).

Adapun tujuan dari pengabdian masyarakar ini adalah memahami gizi seimbang pada anak masa pandemik Covid 19, terbentuknya pokja dan program bersama dengan Puskesmas dalam rangka pemantauan gizi seimbang pada anak di wilayah kerja Puskesmas Kampung Bugis.

\section{TARGET DAN LUARAN}

Sasaran kegiatan ini adalah orang tua dan anak di Desa Sei Nyirih Wilayah kerja Puskesmas Kampung Bugis dengan jumlah anak balita sebanyak 16 balita. Adapun target dan luaran pada pengabdian masyarakat ini adalah : Peserta diharapkan memahami gizi seimbang pada anak masa pandemik covid 19, Peserta diharapkan berpartisipasi mendengarkan dan menyimak kegiatan penyuluhan dari awal hingga akhir, Peserta diharapkan mengikuti proses penyuluhan dengan baik dan teratur, Mendukung dan mengembangkan program yang dapat dilaksanakan pada masyarakat untuk meningkatkan gizi seimbang bagi anak yaitu Pos Pelayanan Terpadu (Posyandu).

Adapun luaran dari pengabdian masyarakat ini adalah terbentuknya pokja dan program bersama dengan Puskesmas dalam rangka pemantauan gizi seimbang pada anak di wilayah kerja Puskesmas Kampung bugis.

\section{METODE PELAKSANAAN}

Langkah-langkah kegiatan ini terdiri dari beberapa tahapan:

1. Persiapan: Survei tempat kegiatan, Persiapan dan ijin tempat, Kontrak dengan kader posyandu dan orang tua balita.

2. Pembukaan : Sosialisasi kegiatan di Posyandu Sei Nyirih, Penyuluhan kesehatan Gizi Seimbang pada anak masa pandemik Covid 19, Pengukuran dan penimbangan anak balita (Pengukuran dan penimbangan oleh anggota pengambas pada 16 anak balita, di bantu oleh kader posyandu)

3. Pemeriksaan deteksi dini tumbuh kembang anak dengan menggunakan KPSP serta stimulasi mainan yang sesuai dengan usia perkembangan (Pemeriksaan deteksi dini menggunakan KPSP oleh anggota pengambas pada 16 anak balita).

\section{HASIL DAN PEMBAHASAN}

Pengabdian masyarakat yang berjudul upaya peningkatan gizi seimbang pada anak di masa pandemi Covid 19 di Wilayah Kerja Puskesmas Kampung Bugis yang terdiri dari Pengukuran dan penimbangan oleh anggota pengambas pada 16 anak balita, di bantu oleh kader posyandu didapatkan data sebagai berikut:

Hasil dari 16 balita yang dilakukan pengukuran dan penimbangan didapatkan 1 anak sangat pendek, 3 anak pendek dan perkembangan anak sesuai format KPSP didapatkan hasil yang sesuai dengan perkembangan pada usia itu. Untuk kegiatan penyuluhan gizi seimbang menggunakan leaflet didapatkan hasil bahwa ibu-ibu memahami tentang pentingnya gizi untuk pertumbuhan dan perkembangan anak balita. Ada beberapa balita yang mengalami tubuh pendek, kepada ibunya disarankan untuk 
memberikan asupan gizi yang seimbang. Balita Pendek (Stunting) adalah status gizi yang didasarkan pada indeks $\mathrm{PB} / \mathrm{U}$ atau $\mathrm{TB} / \mathrm{U}$ dimana dalam standar antropometri penilaian status gizi anak, hasil pengukuran tersebut berada pada ambang batas (ZScore) <-2 SD sampai dengan -3 SD (pendek/ stunted) dan <-3 SD (sangat pendek / severely stunted) (Kementerian Kesehatan Republik Indonesia, 2016)

Stunting disebabkan oleh masalah asupan gizi yang dikonsumsi selama kandungan maupun masa balita. Kurangnya pengetahuan ibu mengenai kesehatan dan gizi sebelum masa kehamilan, serta masa nifas, terbatasnya layanan kesehatan seperti pelayanan antenatal, pelayanan post natal dan rendahnya akses makanan bergizi, rendahnya akses sanitasi dan air bersih juga merupakan penyebab stunting. Multi faktor yang sangat beragam tersebut membutuhkan intervensi yang paling menentukan yaitu pada 1000 HPK ( 1000 hari pertama kehidupan ). Faktor Penyebab stunting juga dipengaruhi oleh pekerjaan ibu, tinggi badan ayah, tinggi badan ibu, pendapatan, jumlah anggota rumah tangga, pola asuh, dan pemberian ASI eksklusif (Wahdah, Juffrie, \& Huriyati, 2015), selain itu stunting juga disebabkan oleh beberapa faktor lain seperti pendidikan ibu, pengetahuan ibu mengenai gizi, pemberian ASI eksklusif, umur pemberian MP-ASI, tingkat kecukupan zink dan zat besi, riwayat penyakit infeksi serta faktor genetik (Aridiyah, Rohmawati, \& Ririanty, 2015).

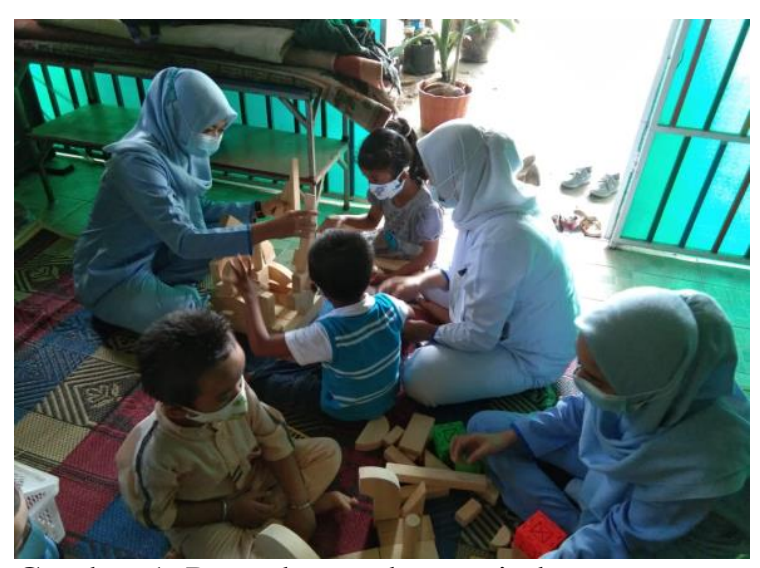

Gambar 1. Pengukuran dan penimbangan

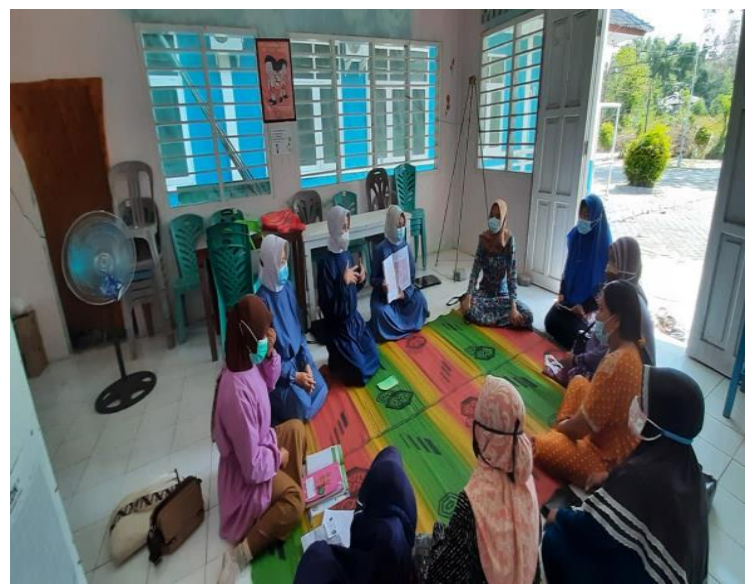

Gambar 2. Kegiatan edukasi

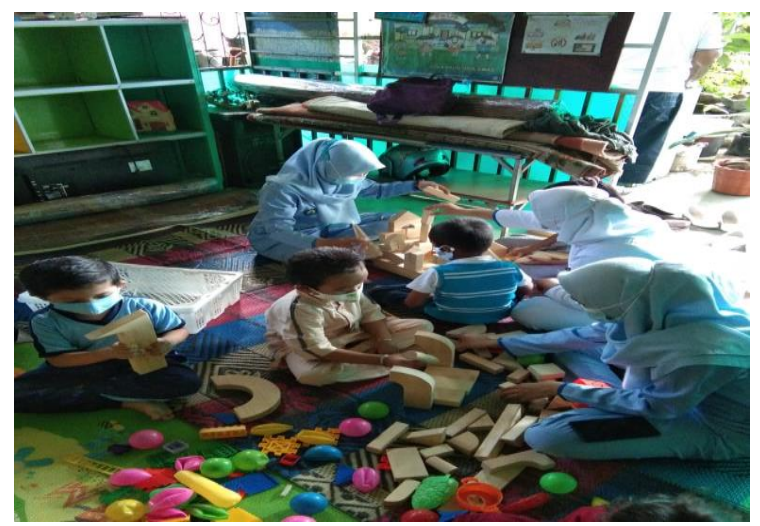

Gambar 3. Pengukuran dan penimbangan 


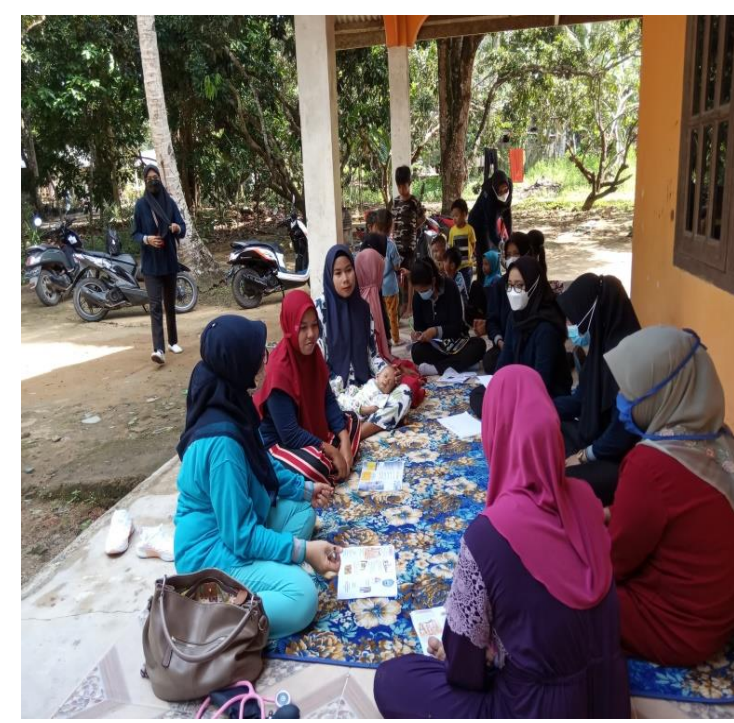

Gambar 4. Pendeteksian menggunakan KPSP

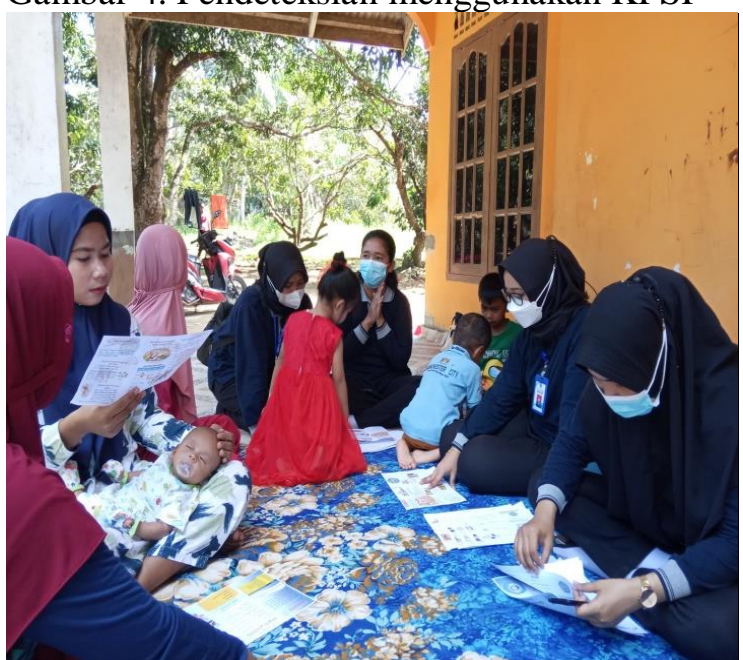

Gambar 5. Pendeteksian menggunakan KPSP

Tabel 1.

Hasil Dengukuran, penimbangan BB dan Derkembangan Anak

\begin{tabular}{|c|c|c|c|c|}
\hline $\begin{array}{l}\text { JENIS } \\
\text { KELAMIN }\end{array}$ & Hour & $B 8 / T B$ & $\mathrm{~TB} / \mathrm{U}$ & $\begin{array}{l}\text { PERKEMMBANGAN } \\
\text { ANAK }\end{array}$ \\
\hline Laki-iaki & 4 tabug $3 \mathrm{bln}$ & Normal & $\begin{array}{l}\text { Sapgat } \\
\text { Perpdels }\end{array}$ & Seswai \\
\hline Laki=laki & 3 蚂 & Normal & Normal & Sesuai \\
\hline Rerempuas & 3 th 6 bular & Normal & Normal & Seswai \\
\hline Laki-Jaki & 3 th 8 bulag & Normal & Normal & Sesuai \\
\hline Laki-laki & 3 th & Normal & Deandels & Seswai \\
\hline Rerempuas & $\begin{array}{l}1 \text { tabua } 9 \\
\text { bulasa }\end{array}$ & Normal & Normal & Seswai \\
\hline Pescepopuas & $\begin{array}{l}1 \text { tabua } 9 \\
\text { bulasa }\end{array}$ & Normal & Peadiek & Seswai \\
\hline Laki-laki & 4 th 9 bulag & Normal & Pendek & Sesuai \\
\hline Laki-Jaki & $\begin{array}{l}1 \text { tabua } 10 \\
\text { bulasa }\end{array}$ & Normal & Normal & Seswai \\
\hline Reremowac & 3 th 1 bulan & Normal & Normal & Seswai \\
\hline Besemopuas & 4 th 7 bula & Normal & Narmal & Seswai \\
\hline Laki-laki & 2 bulan 1 bari & Normal & Normal & Sesuai \\
\hline Pesempuas & 5 bulo 5 basi & Normal & Narmal & Sesuai \\
\hline Laki=laki & 3 th 11 bulag & Normal & Normal & Sesuai \\
\hline Resempuas & 4 th 5 bula & Normal & Normal & Seswai \\
\hline Laki=laki & 1 bulo 30 bast & Normal & Normal & Sesuai \\
\hline
\end{tabular}
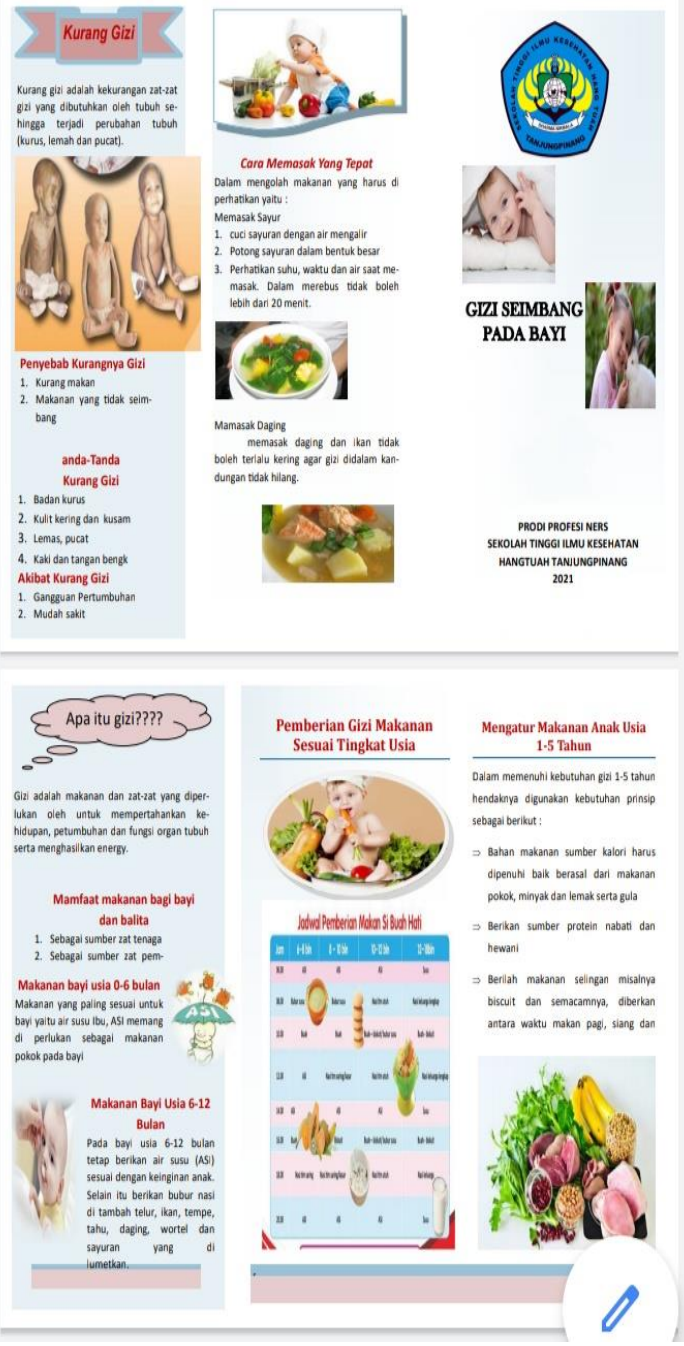

Gambar 6. Leaflet penyuluhaan Gizi Seimbang

\section{KESIMPULAN DAN SARAN}

1. Kesimpulan

Berdasarkan hasil dari pengukuran $\mathrm{TB} / \mathrm{U}$ bahwa di dapatkan ada 1 anak sangat pendek dan 3 anak pendek, dan berdasarkan perkembangan menggunakan kuesioner KPSP didapatkan hasil perkembangan sesuai dengan umur.

\section{Saran}

Disarankan kepada ibu untuk memberikan gizi seimbang kepada balitanya dan kepada kader posyandu untuk rutin mendeteksi pertumbuhan dan perkembangan anak apabila didapatkan anak yang mengalami pertumbuhan yang tidak sesuai maka dapat di carikan solusi dari permasalahan dengan koordinasi kepada pihak terkait. 


\section{UCAPAN TERIMAKASIH}

Ucapan terimakasih Kepala Puskesmas Kampung Bugis, Kader Posyandu, Ketua Stikes Hang Tuah Tanjungpinang, Ka LP3M yang telah memberikan dukungan dan moril semoga kegiatan ini dapat bermanfaat dan diterapkan dalam kehidupan.

\section{DAFTAR PUSTAKA}

Aridiyah, F. O., Rohmawati, N., \& Ririanty, M. (2015). Faktor-faktor yang Mempengaruhi Kejadian Stunting pada Anak Balita di Wilayah Pedesaan dan Perkotaan (The Factors 84 Affecting Stunting on Toddlers in Rural and Urban Areas). E-Jurnal Pustaka Kesehatan, 3(1), 163-170. Ayik Nikmatul Lailli, Al Munawar, F. W

Dimas Rahadian Aji Muhammad, 2020.

Pola Makan Sehat dan Bergizi untuk Meningkatkan Imunitas saat Terserang Covid-19. https://uns.ac.id/id/uns-opinion/polamakan-sehat-dan-bergizi-untukmeningkatkan-imunitas-saatterserang-covid-19.html
Kementerian Kesehatan Republik Indonesia. (2016). Situasi Balita Pendek. ACM SIGAPL APL Quote Quad, 29(2), 63-76. https://doi.org/10.1145/379277.3127 $\underline{26}$

Kemenkes RI, (2016). Pedoman Pelaksanaan Stimulasi, Deteksi dan lntervensi Dini Tumbuh Kembang Anak.

Tri Handayani, Hariyani Nur Khasanah, Rolisda Yosintha (2020). Pendampingan Belajar di Rumah Bagi Siswa Sekolah Dasar Terdampak Covid-19 Abdipraja: Jurnal Pengabdian Kepada Masyarakat e-ISSN: 2746-1823, pISSN: 2745-8415 Volume 1, No. 1, September 2020

Wahdah, S., Juffrie, M., \& Huriyati, E. (2015). Faktor risiko kejadian stunting pada Anak umur 6 - 36 Bulan di Wilayah Pedalaman Kecamatan Silat Hulu, Kapuas Hulu, Kalimantan Barat. Jurnal Gizi Dan Dietetik Indonesia, 3(2), 119-130. 